\title{
Data Analytics Based Risk Management for Students' Performance - A Case Study
}

\author{
M. Somasundaram ${ }^{\mathrm{a}, 1}$, K.A. Mohamed Junaid ${ }^{\mathrm{a},}$ D. Sudha ${ }^{\mathrm{b}}$ \\ and Sabari L. Umamaheswari ${ }^{\mathrm{c}}$ \\ a Department of Electronics and Communication Engineering (ECE), R.M.K. Engineering \\ College, Kavaraipettai, Tamilnadu 601206, India \\ ${ }^{\mathrm{b}}$ Department of Science \& Humanities (S\&H), R.M.K. Engineering College, Kavaraipettai, \\ Tamilnadu 601206, India \\ ${ }^{c}$ Department of Electrical and Electronics Engineering (EEE), R.M.K. Engineering College, \\ Kavaraipettai, Tamilnadu 601206, India
}

\begin{abstract}
Business leaders around the world are using emerging technologies to capitalize on data, to create business value and to compete effectively in a digitally driven world. Among them the risk assessment and the risk management, based on the assessment is a process which can be made using the available past historical data and applying Data Analytics. Although it is being implemented in different business domains, it is at a nascent stage. It is further new and emerging in the area of Education. This paper describes such a process followed in an educational institution of an engineering college and the use of data for risk management. Based on the processes followed, the performance of the students is seen to be improving in academic performance, placement, higher education and entrepreneurship. This also provides a good process and framework for taking strategic initiatives which will give long term benefits in the areas like research and outreach activities.
\end{abstract}

Keywords. Data Analytics, Risk Management

\section{Introduction}

The risk assessment for an organization consists of using the past experience and the knowledge in identifying potential risks, and the possible impacts to the success of the business [1],[2] and [3]. This paper has implemented the Risk Analysis and Risk Management Plan at an institution level in an academic institution with focus on the students' performance in academic and career planning and settlement i.e. job placement, higher studies and entrepreneurship. Based on the processes followed, the performance of the students is seen to be improving in academic performance, placement, higher education and entrepreneurship. This also provides a good process and framework for taking strategic initiatives which will give long term benefits in the areas like research and outreach activities.

1 Corresponding Author, Dr.M.Somasundaram, Professor, Department of Electronics and Communication Engineering, R.M.K. Engineering College, Kavaraipettai, Tamilnadu - 601206, India : Email: mss.ece@rmkec.ac.in 


\section{Methodologies for Data Analytics for Risk Management: Current status}

The risk assessment for an organization consists of using the past experience and the knowledge in identifying potential risks, and the possible impacts to the success of the business [1],[2] and [3]. Big Data Analytics has been used for effective risk management in energy industry [4], banking [5], engineering and construction [6], business operations [7], and higher education [8]. However, in many such areas, as mentioned in their studies, it is at a nascent or early stage.

Typically, it consists of 6 steps: [9]

- Building a library of potential risks,

- Spotting test your data and validating your Key Risk Indicators (KRI),

- Connecting all of your data sources and automating testing,

- Digging deeper into the results and rounding out your analysis,

- Reporting and showcasing your work, and

- Expanding and repeating.

According to Mr. Vivek Katyal, principal, Deloitte \& Touche LLP, Risk Information Services (RIS) practice leader and Audit and Enterprise Risk Services (AERS) leader for Deloitte Analytics, there is a resurgence of interest in the application of analytics to risk management challenges. [10].

\section{Background of the Institutional Process}

The institution, here presented as a case study, is an engineering college namely R.M.K. Engineering College (RMKEC) in India affiliated to Anna University, Chennai, India. RMKEC has been one of the top 10 institutions in Anna University in terms of academic excellence and has been achieving $95 \%$ consistently in the career settlement of students in terms of placement in jobs, higher studies and entrepreneurship. The college has 9 departments with a total number of students of over 3000 . The details can be seen in the college website [11].

The Quality Management System (QMS) process presented has been implemented in the institution over 20 years since 1995. In view of the continuous improvement, the QMS Process has been upgraded in 2017 - 18 to consider a more formal way of addressing risks. The process was upgraded using the framework of ISO 9001: 2015 [12] which laid the processes for Risk Management. The Risk Management was done at the beginning of each academic year at department level as well as college level. Later all the risk management analysis are consolidated at college level and appropriate risk management activities are planned at college level and / or department level.

For the effective identification of risks, each department and the college analyses the data and thus the Data Analytics based Risk Management Process has been implemented in the last 2 years.

\section{The Risk Management Process}

The risk management process being followed as presented in the Figure 1. It has the steps as follows in line with the 6 steps given in [9] 
The Risk Management process consists of steps as follows: Here this process is followed by each of the 8 departments of the college each having a Head of the Department and the faculty members of the department, each department having from 15 to 40 depending on the size of the department)

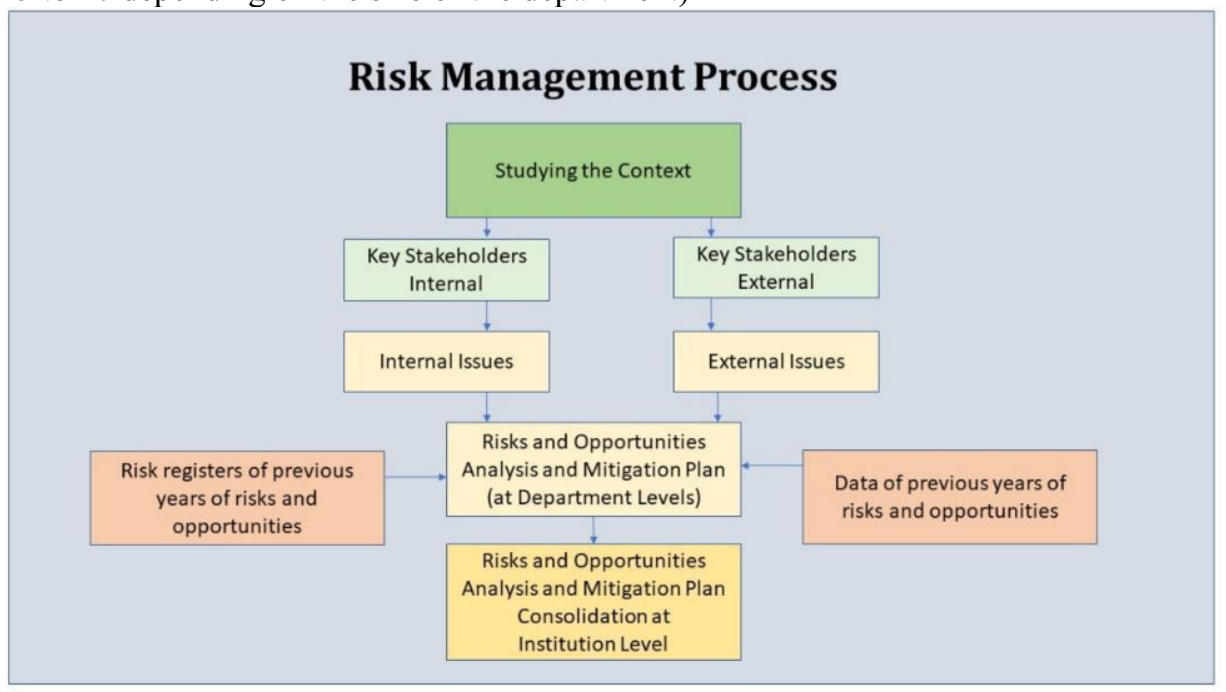

Figure 1. Risk Management Process

Step 1: Building a library of potential risks

When the Risk Management was implemented for the first time, a list was prepared by taking set of risks from existing literature and the past experiences in a qualitative approach. Subsequently as the process was implemented for 2 years, the set of risks identified have been included in the previous existing list.

\section{Step 2: Gathering and testing the background data and validating}

This is done by a process as follows:

Studying the context i.e., business and technical environment of the institution like ranking of the college in the industry, industry requirements of graduands, regulatory requirements like government regulations, University regulations, etc. Such data are collected over the period of time before the actual context study through stakeholders' inputs, updates from university, industry, professional bodies etc.

Identification of key stakeholders' (both internal and external) expectations, the current processes and their effectiveness of satisfying their expectations. In the case of the college, the internal stakeholders are students, faculty members and employees and external stakeholders are parents and alumni, industry (employers of students), regulatory bodies like University, All India Council for Technical Education (AICTE), Accreditation agencies like National Board of Accreditation (NBA), National Assessment and Accreditation Council (NAAC), etc.

Based on the expectations as above, the internal and external issues are identified. Some sample issues are given as illustrative here (not exhaustive). 
Table 1. Sample Internal Issues:

\begin{tabular}{|c|c|}
\hline Number & Internal Issues \\
\hline 1 & Students' performance \\
\hline 2 & Faculty competency \\
\hline 3 & Infrastructure \\
\hline 4 & Changing student culture \\
\hline
\end{tabular}

Table 2. Sample External Issues:

\begin{tabular}{|c|c|}
\hline Number & External Issues \\
\hline 1 & Technology changes needing knowledge update \\
\hline 2 & Social media effecting student's concentration \\
\hline 3 & Changing regulatory requirements \\
\hline 4 & Economic changes affecting placement \\
\hline
\end{tabular}

Step 3: Connecting all of them and analysing to identify the risks and opportunities

Based on the above data collected and the issues identified, the risks and opportunities are identified by using the data as below:

Table 3. Data use for Analytics

\begin{tabular}{|c|c|c|}
\hline Number & Area of Issues and Risk & Data Used for the Analytics \\
\hline 1 & Academic performance & $\begin{array}{ll}\text { - } & \text { Evaluation Results and Causal Analysis for internal } \\
\text { (College level) and external (University) assessments } \\
\text { - } & \text { Students University ranks of past students } \\
\end{array}$ \\
\hline 2 & Placement & $\begin{array}{ll} & \text { Job opportunities in the industry } \\
\text { - } & \text { Past placement data } \\
\text { - Students Employability data (i.e. Aptitude, Soft } \\
\text { skills etc) based on the tests conducted }\end{array}$ \\
\hline 3 & Innovation and Entrepreneurship & $\begin{array}{l}\text { - } \\
\text { - Number of startups } \\
\text { - Number of innovative projects / competitions won } \\
\text { Number of events conducted on innovation and } \\
\text { entrepreneurship }\end{array}$ \\
\hline 4 & Research & $\begin{array}{ll}- & \text { Number of papers published } \\
\text { - } & \text { Funds received for research }\end{array}$ \\
\hline 5 & Students Information & $\begin{array}{l}\text { - Students counseling data of personal information, } \\
\text { mentoring details etc. }\end{array}$ \\
\hline
\end{tabular}

Table 4. Risk Identification and their impact

\begin{tabular}{|l|c|c|c|c|}
\hline Number & Risk & $\begin{array}{c}\text { Event } \\
\text { Likelihood (A) }\end{array}$ & $\begin{array}{c}\text { Affecting Reputation and } \\
\text { Business (B) }\end{array}$ & $\begin{array}{c}\text { Risk Factor } \\
(\mathbf{A} * \mathbf{B})\end{array}$ \\
\hline 1 & $\begin{array}{c}\text { Technology changes } \\
\text { needing knowledge update }\end{array}$ & & & \\
\hline 2 & $\begin{array}{c}\text { Social media effecting } \\
\text { student's concentration }\end{array}$ & & & \\
\hline 3 & $\begin{array}{c}\text { Changing regulatory } \\
\text { requirements }\end{array}$ & & & \\
\hline 4 & $\begin{array}{c}\text { Economic changes } \\
\text { affecting placement }\end{array}$ & & & \\
\hline
\end{tabular}

Note:

Event Likelihood (A)

1. Rarely

2. Occasional

3. Likely

4. Frequent
Affecting reputation and business (B)

1. Minor

2. Moderate

3. Major

4.Critical 
Step 4: Further analysis of the risks and opportunities

Further analysis is done and the risk mitigation plans are incorporated. A typical sample risk analysis consists of

- Risks and opportunities

- Steps taken by institution to address the risk / opportunity

- Rating of Risk Mitigation planned (Rating in a scale 1 to 10 : 10 effective; 1 not effective)

\section{Step 5: The Risk Consolidation}

The Risk Analysis and Mitigation plans are conducted by each of the 8 Departments. Then the Head of the Institution and Quality Management Team review them and consolidate into a single analysis as follows:

- R: Risk Factor : A * B where A : Event Likelihood (1 low to 4 high ) and B : Affecting reputation and business (1 low to 4 high)

- M: Rating of risk mitigation in a scale of 1 to 10 (10 effective; 1 not effective)

- Note: Top 3 or 4 risks for each department are highlighted : Requires close monitoring and addressing the risks

- Note: Bottom 3 or 4 risk mitigation effectiveness ratings for each department are highlighted : Requires close monitoring and improving the effectiveness

A sample risk consolidation is prepared as a final summary for management review and planning

Table 5. Risk Consolidation Plan:

\begin{tabular}{|c|c|c|c|c|c|c|c|c|c|}
\hline No & Risks / Opportunities & \multicolumn{2}{|c|}{ Dept 1} & \multicolumn{2}{|c|}{ Dept 2} & \multicolumn{2}{|c|}{ Dept 3} & \multicolumn{2}{|c|}{ Dept 4} \\
\hline & & $\mathbf{R}$ & $\mathbf{M}$ & $\mathbf{R}$ & $\mathbf{M}$ & $\mathbf{R}$ & $\mathbf{M}$ & $\mathbf{R}$ & $\mathbf{M}$ \\
\hline & $\begin{array}{l}\text { Risks (Examples, not exhaustive } \\
\text { list) }\end{array}$ & & & & & & & & \\
\hline 1 & Poor academic performance & 1 & 8 & 12 & 9 & 12 & 9 & 2 & 8 \\
\hline 2 & Reduction in placement & 4 & 7 & 8 & 8 & 8 & 8 & 4 & 7 \\
\hline 3 & $\begin{array}{l}\text { Environment Factors (eg Rain, } \\
\text { Floods, Pandemic Period ) }\end{array}$ & 2 & 9 & 2 & 6 & 2 & 6 & 9 & 6 \\
\hline & & & & & & & & & \\
\hline 20 & $\begin{array}{l}\text { Aspirants attracted to software } \\
\text { courses }\end{array}$ & & & & & & & 9 & 6 \\
\hline & $\begin{array}{l}\text { Opportunities (Examples, not } \\
\text { exhaustive list) }\end{array}$ & & & & & & & & \\
\hline 1 & Corporate contests eg SIH & & & & 9 & & 9 & & 8 \\
\hline 2 & Intra / Inter dept contests & & & & 9 & & 9 & & 8 \\
\hline 3 & Online certification & & & & 9 & & 9 & & 8 \\
\hline 20 & $\begin{array}{l}\text { Online courses and practice for } \\
\text { coding }\end{array}$ & & & & & & & & \\
\hline
\end{tabular}

\section{Step 6: Communication and Action Planning}

Based on the consolidation, the Head of the Institution communicates the analysis to all the members of the departments and provides the action plans at the institution and department level. The action plans are implemented and monitored regularly on the status and effectiveness of the Risk Management plan. 


\section{Conclusion: Performance of the Students}

The academic performance of the students have been consistent over the last 2 years of $85 \%$ pass percentage. However, the Risk Management has been effective in planning for risks due to COVID 19 in the year $2020-21$. The institution switched over to online mode of teaching and learning and evaluation and effectively conducted the academic activities. It is to be noted that the institution was conferred the status of Autonomous by the Anna University with effect from the academic year $2020-21$. The academic activities related to design of curriculum and syllabus were done effectively. The Autonomous status and the flexibility in designing the curriculum and syllabus will address some of the key risks of changes in technology and changes in the expectations of the industry.

The performance of the student in other key parameters are given as below. Further strategic initiatives have been taken to improve the students' performance on a long term of 2 to 3 years like research etc.

Table 6. Performance of the students: (Some key parameters)

\begin{tabular}{|c|l|c|c|l|}
\hline $\begin{array}{c}\text { N } \\
\mathrm{o}\end{array}$ & \multicolumn{1}{|c|}{ Key Performance Index } & $\begin{array}{c}\text { Year } \\
2019-20\end{array}$ & $\begin{array}{c}\text { Year } \\
2020-21\end{array}$ & $\begin{array}{c}\text { Strategic Initiatives } \\
\text { Taken in 2020 - 21 }\end{array}$ \\
\hline 1 & No. of students placed in jobs & 422 & 443 & Note: Placement is still in progress \\
\hline 2 & $\begin{array}{l}\text { No. of students in High Salary } \\
\text { packages }\end{array}$ & 28 & 58 & Identifying and training high performers \\
\hline 3 & Startup companies by students & 12 & 109 & $\begin{array}{l}\text { Established Institution's Innovation } \\
\text { Council in 2019 }\end{array}$ \\
\hline 4 & $\begin{array}{l}\text { Patents published / granted by } \\
\text { tudents under guidance by } \\
\text { faculty members }\end{array}$ & 0 & 8 & IPR Cell created \\
\hline
\end{tabular}

\section{Future Direction}

As we have initiated Data Analytics based Risk Management, we are currently implementing various tools in Artificial Intelligence and Data Science to consolidate the data and do analytics in terms of diagnosis, and prediction also.

\section{References}

[1] https://www.henryharvin.com/blog/role-of-data-science-in-risk-management/ : Role of Data Science in Risk Management in 2021 [Updated]

[2] https://www.abs-group.com/Knowledge-Center/Insights/What-is-Data-Science-Applying-Analytics-toRisk-Management/ What is Data Science? Applying Analytics to Risk Management

[3] https://financetrain.com/role-of-data-science-in-risk-management/ Role of Data Science in Risk Management

[4] Application of big data analytics in process safety and risk management: Pankaj Goel, et al, 2017 IEEE International Conference on Big Data (Big Data), https://ieeexplore.ieee.org/abstract/document/8258040

[5] Risk Management 4.0: The Role of Big Data Analytics in the Bank Sector: Dicuonzo, Grazia et al, International Journal of Economics and Financial Issues; Mersin Vol. 9, Iss. 6, (2019): 40-47. https://www.proquest.com/openview/890e7032744535a4ff6f5c2f5efb079a/1?pqorigsite $=$ gscholar $\& \mathrm{cbl}=816338$ 
[6] Data Analytics for Engineering and Construction Project Risk Management (2020) : Ivan Damnjanovic et al, ISBN: 978-3-030-14251-3 (2020) , Springer Link, https://link.springer.com/book/10.1007\%2F9783-030-14251-3

[7] Recent Development in Big Data Analytics for Business Operations and Risk Management : Tsan-Ming Choi et al, IEEE Transactions on Cybernetics (Volume: 47, Issue: 1, Jan. 2017), https://ieeexplore.ieee.org/abstract/document/7378465

[8] Opportunities and challenges for big data analytics in US higher education: A conceptual model for implementation: Mohsen Attaran, et al, Sage Journals, April 26, 2018https://journals.sagepub.com/doi/abs/10.1177/0950422218770937

[9] https://www.wegalvanize.com/risk/data-analytics-risk-assessments/: 6 steps to start using data analytics for risk assessments

[10] https://www2.deloitte.com/content/dam/Deloitte/au/Documents/risk/deloitte-au-risk-risk-anglesapplying-analytics-risk-management-250215.pdf : Deloitte : Risk Angles Five questions about applying analytics to risk management

[11] www.rmkec.ac.in : R.M.K. Engineering College

[12] https://www.iso.org/standard/62085.html : ISO 9001:2015 : Quality management systems Requirements 